\title{
РЕАЛІЗАЦІЯ ДИДАКТИЧНИХ ПРИНЦИПІВ У ПРАКТИЦІ НАУКОВОЇ ПІДГОТОВКИ ІНОЗЕМНИХ СТУДЕНТІВ ДО НАВЧАННЯ В МЕДИЧНОМУ УНІВЕРСИТЕТІ
}

\author{
Ivano-Frankivsk National Medical University \\ REALIZATION OF DIDACTIC PRINCIPLES IN THE PRACTICE OF \\ SCIENTIFIC TRAINING OF FOREIGN STUDENTS TO STUDYING \\ IN A MEDICAL UNIVERSITY
}

\begin{abstract}
Мета роботи - розкрити особливості реалізації основних дидактичних принципів у процесі загальнонаукової підготовки іноземних студентів до навчання у медичному вузі.

Основна частина. Проаналізовано останні дослідження і публікації щодо підготовки іноземних студентів у ВНЗ. Реалізація принципу урахування рівня володіння мовою навчання означає, що при навчанні мовою-посередником (російською чи українською) необхідно ураховувати етапи оволодіння нерідною мовою, їх недостатній словниковий запас у процесі підготовки. Так, на різних етапах навчання іноземні студенти-медики володіють по-різному обмеженим, а на початковому етапі вкрай недостатнім, лексичним арсеналом, мовними засобами і способами сприйняття й подання інформації.

Висновки. Застосування загальних дидактичних принципів при навчанні іноземних студентів-медиків $є$ необхідною, але недостатньою умовою для успішної організації навчального процесу, бо кожний із принципів у певних умовах залежить від контингенту іноземних студентів-медиків, рівня їх базової підготовки, володіння ними мовою-посередником (російською чи українською), їх психоемоційного стану, а також від характеру навчального матеріалу, певного навчального завдання та від інших факторів, що є специфічними саме для навчання нерідною мовою у нерідному середовищі.
\end{abstract}

Ключові слова: іноземні студенти; підготовчий факультет; загальнонаукова підготовка; дидактичні принципи.

The aim of the work - to reveal the peculiarities of the implementation of the basic didactic principles in the process of general scientific training of foreign students for studying at a medical school.

The main body. The last researches and publications concerning training of foreign students in higher educational institutions are analyzed. The implementation of the principle of taking into account the level of language proficiency means that when learning a language-intermediary (in Russian or Ukrainian), it is necessary to take into account the stages of mastering a non-native language, their lack of vocabulary in the preparation process. Thus, at different stages of training foreign medical students have differently limited, and at the initial stage, extremely inadequate, lexical arsenal, linguistic means and methods of perception and presentation of information.

Conclusions. It is necessary to apply general didactic principles to the teaching of foreign medical students, but insufficient condition for the successful organization of the educational process, since each of the principles depends on the contingent of foreign medical students, the level of their basic training, their possession in the language of the mediator (in Russian or Ukrainian), their psycho-emotional state, as well as the nature of the educational material, the particular learning task and other factors that are specific to learning a nonnative language in non-native environments

Key words: foreign students; preparatory faculty; general scientific training; didactic principles.

Вступ. Однією із важливих складових міжнародної діяльності вищої освіти України є підготовка фахівців для зарубіжних країн. Кількість іноземних громадян, які прагнуть здобути вищу освіту у вітчизняних вишах, щороку збільшується. Найбільш затребуваною для них $є$ медична спеціальність.
Різні аспекти підготовки іноземних студентів у ВНЗ вивчали українські та зарубіжні дослідники: Н. Булгакова, В. Бевз, М. Іванова, Л. Корочкіна, Л. Куришева, Л. Рибаченко, О. Суригін, О. Філіпова, О. Хачатурова, Т. Шмоніна та ін. Проте аналіз науково-педагогічної літератури щодо підготовки іноземних студентів у ВНЗ дозволив зробити вис-

(C) Т. Л. Ленчук 
новок, що найбільш активно досліджуються проблеми їх навчання російської та української мов. Водночас особливості та проблеми готовності іноземних студентів-медиків до професійної діяльності майбутніх лікарів виявились недостатньо розробленими. Підготовка іноземних студентів відіграє вагому роль у розв'язанні завдань щодо їх навчання, виховання і розвитку, готовності до подальшої трудової діяльності. Щоб випускник був готовий до подальшої праці, необхідно так організувати навчальний процес, щоб усі його елементи були скоординовані і давали бажаний навчальновиховний ефект. Тому для обгрунтування і реалізації визначених нами організаційно-педагогічних умов (інтегрування мовних і предметних знань 3 урахуванням регіонально-психологічних особливостей студентів-іноземців та специфіки їх адаптації до нерідного соціокультурного й освітнього середовища; впровадження інноваційних технологій у навчальний процес з урахуванням поетапності оволодіння іноземними студентами загальнонауковими знаннями нерідною мовою; модернізація традиційних форм, методів та засобів навчання відповідно до специфіки суб'єктів навчання та етапів навчально-виховного процесу з різних регіонів світу) вважаємо за необхідне проаналізувати роль дидактичних принципів у процесі підготовки до подальшої праці.

Мета роботи - розкрити особливості реалізації основних дидактичних принципів у процесі загальнонаукової підготовки іноземних студентів до навчання у медичному вузі.

Основна частина. Відомо, що головними особливостями ефективного навчання $є$ як накопичений досвід роботи з іноземними студентами, так і базові теоретичні “положення, що визначають зміст, організаційні форми і методи навчальнопізнавального процесу” відповідно до його цілей i завдань [2]. У дидактиці означені положення формулюються у вигляді принципів навчання (дидактичних принципів). Вони повинні “охоплювати своїм спрямованим, регулюючим впливом найважливіші елементи процесу навчання - його зміст, методи, організаційні форми - і не зводитись ні до яких інших положень, не замінюватись ними” [3]. Успішне конструювання чи вдосконалення методики навчання можливе за умов системного застосування дидактичних принципів. Критері$\epsilon м$ введення певного теоретичного положення у систему принципів навчання іноземних студентів
$€$ відображення даним положенням особливостей процесу навчання нерідною мовою у нерідному середовищі [5]. Тому до найбільш важливих дидактичних принципів при удосконаленні методики ми віднесли як класичні (єдності навчання, виховання та розвитку; науковості і систематичності; усвідомленості і творчої активності у навчанні; стійкості засвоєння знань, умінь та навичок; диференційованого підходу; навчання на високому рівні труднощів; розвиваючого навчання), так і специфічні для системи навчання іноземців положення (урахування базового загальнонаукового рівня та володіння мовою навчання; урахування рівня адаптації і національно-культурних особливостей іноземців; навчання нерідною мовою з урахуванням професійної направленості) [4].

Розглянемо застосування деяких найважливіших дидактичних принципів більш детально.

1. Принцип науковості і систематичності. Принцип науковості передбачає, що зміст навчального матеріалу відповідає рівню сучасних знань, а технологія викладання відповідає їм (це вимагає постійного удосконалення курсів і методів їх викладання; єдності теорії і практики; більш повного відображення у навчальному процесі методів наукових досліджень). Науковість та глибина викладання загальнонаукових дисциплін значною мірою визначається також і тим, наскільки повно і правильно викладачі-предметники користуються медичними термінами для розкриття дії законів або для отримання наслідків із загальних положень. Урахування того, що систематичність у навчанні досягається певною побудовою дисциплін, при якій програмний матеріал вивчають у чіткій послідовності, що відповідає логіці науки, дало змогу при вивченні кожного факту спиратись на знання вивченого раніше і в той же час готувати основу для вивчення нового. Принцип систематичності передбачав формування у студентів-іноземців системи наукових понять, знань, вмінь та навичок. Систематизація, відіграючи велику роль у розвитку мислення, також дозволяє більш продуктивно використовувати пам'ять, оскільки звільняє від необхідності заучувати матеріал як суму окремих відомостей і фактів за рахунок групування їх у більш крупні блоки інформації, які легше запам'ятати і відтворити у разі необхідності. Важливу роль у здійсненні цього відіграє вивчення теорій, які дозволяють пояснити широке коло явищ з наукової точки зору, а також класифікація об’єктів по групах на основі 
встановленої схожості і відмінності між ними, що не тільки впорядковує знання іноземних студентів, а й слугує джерелом нових знань. Логічно розроблені нами навчальні програми створюють умови для систематизації знань іноземних студентів, але лише вони не забезпечують розв’язання цієї проблеми, тому ми вважаємо необхідним використання різних технологій систематизації матеріалу й ознайомлення $з$ ними студентів $з$ метою свідомого застосування в процесі навчальної діяльності.

2. Особливе місце при навчанні ми надали принципу наочності, здійснення якого сприяє усвідомленому і глибокому засвоєнню матеріалу, розвитку уваги, пам’яті, творчих здібностей студентівмедиків. Наочність навчання забезпечує створення в іноземних студентів уявлень і понять на основі живого сприйняття предметів і явищ, що вивчаються на заняттях. Застосування наочності у поєднанні зі словами викладача активізує першу і другу сигнальні системи, що сприяє засвоєнню матеріалу нерідною мовою. Наочність при викладанні загальнонаукових дисциплін досягається перш за все демонстрацією дослідів, діючих і схематичних моделей, постановкою фронтальних лабораторних робіт та експериментів; разом з тим доцільним є використання зображення предметів і явищ: схем, рисунків, слайдів, плакатів, навчальних кінофільмів. Під час демонстраційних дослідів студенти-медики користуються зоровими та слуховими сприйняттями, а під час виконання лабораторних робіт й іншими (дотик, нюх, мускульно-рухові сприйняття), у результаті чого сприйняття стає більш повним, глибоким та осмисленим. Оскільки вивчення загальнонаукових дисциплін не обмежене часом, то для оптимізації навчального процесу і 3 метою підвищення його ефективності ми використовували сучасні засоби наочності, застосовували комп’ютерну техніку, за допомогою якої проводили лабораторні роботи, демонстрували різні явища у динаміці тощо.

3. Принцип усвідомленості й активності. Цей принцип передбачає особливості процесу навчання, коли іноземні студенти засвоюють необхідні знання і навички свідомо й глибоко в результаті активної навчальної діяльності, що проходить у новому для них оточуючому середовищі нерідною мовою. Усвідомленість і активність студентів в отриманні знань тісно пов'язані з принципом керівної ролі викладача в навчальному процесі. Суть його в тому, щоб забезпечити оптимально сприят- ливе співвідношення педагогічного керівництва і свідомої праці іноземних студентів-медиків на заняттях, виходячи $з$ того, що їх свідоме ставлення до навчання починається з розуміння завдань i необхідності отримання майбутнього медичного фаху, зародження інтересу до професії. Залежно від поставлених завдань на заняттях із загальнонаукових дисциплін ми використовували різні методи і прийоми, що забезпечують активність у навчанні. При вивченні нового матеріалу цій меті слугують: проблемне навчання (створення різними способами проблемних ситуацій); цікава й зрозуміла (в доступному темпі і без складних граматичних конструкцій) та проста для розуміння студентамиіноземцями розповідь викладача; демонстрації дослідів; самостійна робота студентів з підручником тощо. При перевірці знань, навичок і вмінь, тобто при розв’язанні задач і вправ, активність мислення і дій іноземних студентів досягається попереднім відпрацюванням певних елементів розв'язання, індивідуалізацією завдань, постановкою питань, що потребують порівняння досліджуваного явища або властивості з іншими і т. д. Зауважимо, що до самостійного розв'язання задач іноземні студенти переходять, навчившись працювати за зразком, що надає викладач. Ми враховували, що інтерес (короткочасний і стійкий) до предметів визначається цілим рядом факторів: змістом програм, якістю підручників, методами навчання, індивідуальними особливостями студентів, особистими якостями викладача. Короткочасний інтерес викликати не важко і досягається ефективно поставленими експериментами, демонстраціями кінофільмів, яскраво оформленими наочними посібниками.

4. Принцип стійкості засвоєння знань, вмінь та навичок. Основою цього принципу є вимога глибокого й усвідомленого засвоєння знань, оволодіння вміннями та навичками. Обсяг та глибина засвоєних знань безперечно залежать від властивостей пам'яті студента-медика. Отже, щоб забезпечити іноземним студентам отримання глибоких, дієздатних загальнонаукових знань, вмінь та навичок, ми звернули увагу на важливість розвитку їх логічної пам'яті, що спирається на усвідомлене й творче засвоєння матеріалу. Виходячи із закономірностей процесів пам’ яті і запам’ ятовування, для успішності принципу стійкості засвоєння знань, вмінь і навичок ми акцентували увагу на деяких важливих положеннях методики викладання загальнонаукових дисциплін студентам-іноземцям: стійкості знань 
можна досягнути за рахунок їх структурування (розкриття спочатку найближчих, а потім все більш віддалених взаємозв'язків; роз'яснення на основі встановлених моделей механізму перебігу процесів і явищ); основним засобом створення стійких знань і навичок у студентів $€$ широке використання усіх видів вправ, задач, фізичних та хімічних експериментів; вивчення явищ, законів доцільно так, щоб спочатку розглядався лише основний їх зміст, а потім (при закріпленні знань і подальшому оволодінні науковою термінологією) поступово розширювався їх об’єм - наводились нові приклади, положення і т. д.; в міру оволодіння новими знаннями науковими, так і мовними потрібно організовувати самостійну роботу іноземних студентів-медиків розв’язання задач, відповіді на запитання (письмові і усні), підготовка до лабораторних робіт та їх виконання тощо; вказувати на матеріал, що потребує запам'ятовування, звертаючи на це особливу увагу студентів-медиків; з метою вироблення навичок розумової діяльності іноземним студентам корисно надавати для запам'ятовування алгоритми розв'язання основних видів навчальних задач, плани узагальненого характеру для усних відповідей на запитання, описи фізичних явищ тощо [1]. Для успішності реалізації принципу стійкості засвоєння знань, умінь та навичок ми використовували оптимальні поєднання аудиторних, позааудиторних, а також індивідуальних форм навчання. Тому доцільним вважаємо тимчасовий поділ студентської групи на частини (підгрупи) для виконання вправ, задач та іншої навчальної діяльності. При цьому підгрупі 3 найбільш підготовлених студентів-медиків ми давали завдання підвищеної складності, підгрупі слабких за знаннями - завдання, які б вони були спроможні розв’язати після пояснень. Як показав наш досвід, іноді корисно об’єднувати для спільної роботи сильних і слабких студентів для того, щоб забезпечити взаємодопомогу при виконанні

\section{Список літератури}

1. Булгакова Н. Б. Система пропедевтичної підготовки іноземних громадян з природничих дисциплін у технічному університеті : дис. ... доктора пед. наук: 13.00.04 / Булгакова Наталія Борисівна. - К., 2002.- 446 с.

2. Булгакова Н. Б. Методика викладання у вищій школі: навч. посіб. / Н. Б. Булгакова, В. О. Рахманов. - К. : HAУ, 2012. - 204 c.

3. Скаткина М. Н. Дидактика средней школы: некоторые проблемы современной дидактики : учебная книга / М. Н. Скаткина.- М. : Просвещение, 1982. - 319 с. лабораторних робіт, розв’язанні типових задач. При індивідуальній формі роботи кожний студентмедик виконує завдання самостійно на рівні своїх максимальних (на даний момент) можливостей.

5. Реалізація принципу урахування рівня володіння мовою навчання означає, що при навчанні мовою-посередником (російською чи українською) необхідно ураховувати етапи оволодіння нерідною мовою, їх недостатній словниковий запас у процесі підготовки. Так, на різних етапах навчання іноземні студенти-медики володіють по-різному обмеженим, а на початковому етапі вкрай недостатнім, лексичним арсеналом, мовними засобами і способами сприйняття й подання інформації. 3 метою ефективного обміну інформацією ми використовували лише адекватні для сприйняття іноземцями мовні засоби і методи презентації навчального матеріалу, тобто звертали увагу на те, що урахування володіння нерідною мовою студентами-іноземцями вимагає коректного лінгвометодичного оснащення занять і створення навчально-методичної літератури із загальнонаукових дисциплін у відповідності з етапом її вивчення.

Висновки. Таким чином, застосування загальних дидактичних принципів при навчанні іноземних студентів-медиків є необхідною, але недостатньою умовою для успішної організації навчального процесу, бо кожний із принципів у певних умовах залежить від контингенту іноземних студентів-медиків, рівня їх базової підготовки, володіння ними мовою-посередником (російською чи українською), їх психоемоційного стану, а також від характеру навчального матеріалу, певного навчального завдання та від інших факторів, що є специфічними саме для навчання нерідною мовою у нерідному середовищі.

Перспективи подальших досліджень: подальше вивчення принципів та особливостей навчання іноземних студентів дозволить значимо підняти рівень їх професійної та наукової підготовки як майбутніх лікарів.

4. Довгодько Т. І. Загальнонаукова підготовка іноземних студентів до навчання в університеті : автореф. дис. на здобуття ступеня канд. пед. наук: спец. 13.00.04 “Теорія і методика професійної освіти” / Т. І. Довгодько. - К., 2014. - 20 с.

5. Сургин А. И. Дидактические основы предвузовской подготовки иностранных студентов в высших учебных заведениях : дисс. ... д-ра пед. наук: 13.00.08 / Сурыгин Александр Игоревич. - СПб., 2000. - 278 с. 


\section{References}

1. Bulhakova, N.B. (2002). Systema propedevtychnoi pidhotovky inozemnykh hromadian z pryrodnychykh dystsyplin u tekhnichnomu universyteti [The system of propaedeutic training of foreign citizens from natural sciences at the technical university]. Doctor's thesis. Kyiv [in Ukrainian].

2. Bulhakova, N.B. (2012). Metodyka vykladannia u vyshchii shkoli. Navchalnyi posibnyk [Teaching method in high school. Tutorial]. Kyiv: NAU [in Ukrainian].

3. Satkina, M.N. (1982). Didaktika sryedney shkoly: nyekotoryye problemy sovryemennoy didaktiky [Didactics of high school: some problems of modern didactics]. Moscow: Prosvyeshcheniye [in Russian].
4. Dovhodko, T.I. (2014). Zahalnonaukova pidhotovka inozemnykh studentiv do navchannia v universyteti [General scientific training of foreign students for university studies]. Extended abstract of Doctor's thesis. Kyiv: NAU [in Ukrainian].

5. Surgin, A.I. (2000). Didaktichieskiye osnovy predvuzovskoy podgotovki inostrannykh studentov v vysshykh uchebnykh zavedeniyakh [Didactic bases of pre-university training of foreign students in higher educational institutions]. Doctor's thesis. Saint-Petersburg [in Russian].

Отримано 11.01.18

Електронна адреса для листування: tatyanalenchuk@gmail.com 